\title{
Beyond the Westphalian rainbow: a dissident theory of supranational systems
}

\author{
Ipek Zeynep Ruacan
}

\section{iruacan@yahoo.com}

Parts of this article were written at Koc University, Rumelifeneri Yolu, 34450, Sariyer, Istanbul, Turkey.

+902123381000

This article focuses on the work of Adam Watson from the English School of International Relations for two purposes. The first is to highlight the potential it contains for transcending the prejudices imposed upon IR theory by the anarchy assumption and by the reification of independent statehood. The second and the more specific purpose is to understand the formation of legitimate supranational systems once these prejudices are removed. Watson approaches supranationalism as an extant condition in international society rather than as a deviation from a normal condition of anarchy or independent statehood; and proposes a culturalist and a moralistic framework in which supranational systems can be legitimized. As a case study to determine which framework is more valid, I analyzed the Convention on the Future of Europe and concluded that the moralistic serves better for understanding how the EU is legitimized. Once juxtaposed with NeoWeberian historical sociology's insights into the state, Watson's moralistic framework can offer a foundational theory for re-considering legitimate supranational systems and open up new research agendas in IR theory. 
Keywords: English School, Adam Watson, historical sociology, EU Constitution, hegemony, anarchy

This article examines supranational systems through the work of the English School of International Relations' (ES) Adam Watson - a key figure in the British Committee on the Theory of International Politics out of whose discussions the School grew, and the Committee's third chairperson following Herbert Butterfield and Martin Wight (Vigezzi, 2005). If E.H. Carr was a 'dissident voice' (Dunne, 1998, p.13) to this academic community, then Watson was its dissident chairperson in that his studies never fully matched the broader debate in the Committee. Watson's research aligns closer with the emerging literature on hierarchy, pioneered among others by Lake (2009), than with the rest of the early ES research. I charted Watson's work through the years from a Toynbee style history-writing through to a Neo-Gramscian interest in hegemony. Subsequently, I tested his ideas on the formation of supranational systems at a critical moment in the history of European integration, the European Convention and the drafting of the Constitutional Treaty. The result was a foundational theory of supranational systems once Watson's approach is juxtaposed with Neo-Weberian research on the state in particular.

The article proceeds in three sections to highlight Watson's approach. The first section provides an overview of the key terms and arguments as well as the weaknesses in his research. The second section turns to the EU to see if its evolution can verify Watson's thesis on the formation of supranational systems. For this purpose, I analyzed the debate held at the European Convention that gathered to draft a Constitutional Treaty for the European Union; and the analysis did partially substantiate Watson's approach. The third section elaborates the 
rationale for incorporating Neo-Weberian analyses of the state into the ES argument for a more coherent approach to the formation of supranational systems.

Let me first briefly elaborate the reasons for bringing in the ES to the study of the EU and for focusing on Watson from within the ES itself. As Manners and Whitman have noted, we are facing a double crisis at the moment: one within the EU itself and the other within the field of EU studies as a gap has opened between the practical realities and the dominant theories of the EU (2016). One way to bridge this gap is to connect EU studies to broader debates in the social sciences. On this basis, Buzan once noted that the ES is 'admirably suited' for analyzing the EU under a comparative/ historical framework as the organization offers, on a regional scale, the most developed example of an international society the School has extensively examined (2001, p.485). Watson himself merits special attention for two reasons. The first is specific to my study in which I analyzed the views of the key founding members of the ES in comparison. My findings justified the views of Watson more so than Martin Wight, Hedley Bull and Raymond John Vincent. The attention I am paying on Watson is thus partially dictated by my own research results.

There is also a general reason that justifies greater engagement with Watson's work, and that is its potential in transcending the 'territorial trap' (Agnew, 1994) and the 'Westphalian deferral' (Blaney \& Inayatullah, 2000) characterizing much of mainstream IR theory. The territorial trap and the Westphalian deferral both impose a state-centric bias on IR theory and lead us to ignore a number of critical issues. The first such critical issue is the hierarchical ordering of states in international society and the 'capacities of states in different global situations to exercise de facto sovereignty internally and externally' (Agnew, 2005, p. 438). Surely, not all states are capable of exercising sovereignty in the way state-centric IR 
theory expects them. The second and related issue is the assumption that the international is strictly 'anarchical' which leads on to the other assumptions that there is a rigid inside/outside divide; and that all states are 'like units' (Waltz, 1979) struggling to survive under a hostile anarchy as Milner (1991) reminds. And third, as the international is presumed to be hostile, Westphalian IR theory also 'defers' normative issues to the boundaries of states (Blaney \& Inayatullah, 2000). Incidentally, Blaney and Inayatullah (2000) offer the works of Bull (1995) and Wight (1960) (alongside Michael Walzer) as archetypal examples of the 'Westphalian deferral'.

Watson's research has the potential to overcome these limiting presuppositions and has indeed started receiving more attention in recent years as the literature around hierarchy develops. To begin with, Watson (as well as Wight) has been one of the earliest proponents of the argument that the equality of states is a mistaken assumption and that international society is arranged hierarchically. The capacities of states to act are restricted by their place in this hierarchy. Watson maintains that there is currently an aid/donor hierarchy in international society and that recipient states act based on their degree of dependence on aid (1997). Obviously, this is also a rejection of the argument that states are 'like units' (Waltz, 1979). A recipient state and a donor state function differently from one another. Furthermore, Watson's (1992) pendulum metaphor (details below) maintains that a purely anarchical system is only a theoretical possibility that has never materialized in history, and that the inside/outside dichotomy becomes increasingly more meaningless as we move along this 
pendulum. Once Watson rejects the possibility of a purely anarchical international system, his path toward arguing that the international too can be 'good' is also cleared. Therefore, there remains no need to vacate the international from normative concerns. As we will see below, the pendulum metaphor also allows us to operate with notions of 'divisible sovereignty and deterritorialized legitimacy' (Agnew, 2005, p.439) that are called for in an increasingly globalizing system. Indeed, Watson (1992) makes the case that sources of legitimacy can be found in cultural or moral ideals rather than in territorial states only, and that sovereignty has never been entertained in absolute terms by any state in the first place. The international constantly infringes upon that sovereign capacity. It cannot be otherwise since one can only be a state inside the system of states. And once in the system, members are 'schooled in the - sometimes disappointing and painful - limits of independence, and come to accept the seeming paradox that the interdependence which provides them with a means of bringing pressure to bear on other states equally restricts their own freedom of action' (Watson, 1982, p.169).

Watson's research is thus particularly well-equipped to cope with the 'territorial trap' (Agnew, 1994) and the 'Westphalian deferral' (Blaney \& Inayatullah, 2000) in IR theory albeit with one reservation, and that is his weak conception of the state. Watson avoids the three limiting assumptions of IR theory but cannot avoid the fourth, namely, to 'dehistoricize and decontextualize processes of state formation and disintegration' (Agnew, 1994, p.59) around the world. This fourth issue is precisely why a historical sociology of the state is required in Watson's research. Let us now turn to the details of his arguments.

\section{An Overview of Watson's Work}


In a 1972-letter to Butterfield, Watson (2007, p.4) wrote that he kept considering the 'nonvital interests of states and dynasties and communities, that militate against raison d'etat...', and that he would pursue his own inquiry into these issues independently of the British Committee. This inquiry led to a questioning of state-centric IR theories and a revisionist theory of independence. The emphasis is on political communities rather than states, and independence is treated as a relative rather than an absolute concept. The outcome can best be characterized as a 'therapeutic re-description' with a view to 'describing old things in new ways in the hope of reconstituting human experience' (Deibert, 1997, p.182). Watson undertakes to reshape our understanding of 'independence' in this fashion, and treats the idea of an international politics conducted by absolutely independent states simply as a hypothetical condition. The Evolution of International Society (1992) re-describes a limited notion of independence with reference to a metaphorical pendulum of independence, hegemony, dominion and empire. The two end points of independence and empire are both unstable as they respectively contain too little and too many restrictions on independence. To avoid such instability, the pendulum eventually returns to its middle area of hegemony/dominion which restrict independence at varying degrees of supranational authority (Watson, 1992). Full independence is a myth then - Watson $(2007$, p.87) defines it as a 'crock of fairy gold at the end of the Westphalian rainbow'. By re-describing independence in this way, Watson not only provides

a major alternative to realism, but also challenges the general linkage between anarchy and international society in much of the English School writing. In effect, Watson extends the idea of international society away from the assumption of anarchy and into the spectrum of his pendulum theory (Buzan \& Little, 2009, p. xxvi). 
Much of the classical ES writing does concentrate on how order becomes possible under anarchy. In distinction, Watson concentrates on how order obtains under hierarchy too without refuting the idea of international society itself. A hierarchical international society thus becomes just as possible as an anarchical one. Watson also marks his pendulum with an underlying dilemma between order vs. independence where 'order' refers broadly to 'peace and prosperity' (Watson, 1992, p.14). A less independent system delivers more order while a more independent system delivers less order (Watson, 1992). Bull established a similar dilemma between order and justice where order refers to 'a pattern of human activity that sustains elementary, primary or universal goals of social life' $(1995$, p. 4). Watson agreed with Bull in maintaining that principles of justice can clash with the principles of order in international society, and set a distinction between 'compatible' and 'incompatible' demands on international society. Justice belongs to the realm of incompatible demands as each member may attach a different meaning to it and in some cases it will have re-distributive implications which may leave some worse-off. However, peace is a compatible goal that can be defined objectively (Watson, 2007, pp. 41-2). Neither would peace leave some worse-off since all members of international society can have peace at the same time (Watson, 1982, p.37). Likewise, independence is a compatible demand in that all states in international society can, at least in theory, be independent at the same time (Watson, 1982, p.55). The order vs. justice dilemma set by Bull (1995) thus differs from the order vs. independence dilemma set by Watson (1992). Bull considers how to reconcile subjective/incompatible demands in international society whereas Watson considers how to reconcile the costs of two objective/compatible demands: independence costs peace, and peace costs independence. Legitimacy is a key term within the terms of this dilemma in that less independence becomes 
more possible to the extent that it is legitimate to the members of international society (Watson, 1992).

Legitimacy is 'the degree of independence and supranational authority (the position in the spectrum) and the rules and institutions which the members publicly recognize as binding' (Watson, 1997, p.149). It indicates how much supranational authority is acceptable to a given community which is largely a culturally-determined condition. Those sharing a similar culture are more inclined to restrict their independence as 'membership of the same culture' supposedly 'condition[s] the behavior of political entities to another, and imposes significant though uncodified limits on their independence' (Watson, 1997, p.99).

Watson follows a tradition of history-writing associated with Arnold Toynbee in this definition who suggested that history could only be told in the form of grand narratives where civilizations are the primary units. For Toynbee, nations do not have their own histories as such - each nation's history is grounded within a broader civilization (Martel, 2004, p.347). Yet the weakness in this methodology is that nations disappear in the end. A particular weakness in Toynbee's research was that he failed to do 'justice to the historical reality of national life, of national desire for self-preservation or even expansion' (Geyl, 1948, p. 121). All the more problematic was Toynbee's treatment of the Western civilization which he took as a single homogenous unit. Toynbee merely 'belittle[d] the national factor' in describing the Western civilization in an 'impossibly universalist system' of his own-making (Geyl, 1948, p.123).

Watson likewise overlooks the formation of nations and undermines the nation-state as a unit of analysis particularly when he discusses a universalist Europe of his own. Halliday (2009, p.19) suggested that history-writing in the ES suffers from 'ahistorical continuism' 
which overlooks distinctions between pre-modern and modern times. Watson's (1992) pendulum analogy indeed relies too heavily upon pre-modern systems. This over-reliance manifests itself particularly strongly when Watson reflects the traditions of Latin Christendom onto contemporary Europe; ignoring along the way how nation-states have individuated a once more united Europe. For Watson, the European nation-state represents the artificial break-down of the republic of Europe into separate units, and those European states which pursue nationalistic goals have dropped raison d'etat for 'passion d'etat' (1997, p.19). Watson ultimately disbelieves in nation-states but does not tell us what to do with them in our attempts to understand particular issues in international affairs like the formation of supranational systems.

The nation itself poses a particular problem for the ES' concept of 'world society' which refers to a 'nascent society of all mankind' (Manning, 1975, p.177) and is 'fundamental, primordial and morally prior' (Bull, 1995, p.21) to states or to any other political entity. Watson and Wight take world society to refer to a common culture among a particular group of humans instead of all humankind (Buzan, 2001, p.477). Yet nations constitute the anti-thesis of this cultural sense of world society, and we cannot de-limit the concepts of nations and world society if the latter takes on a cultural meaning. A nation too 'defines and legitimates politics in cultural terms, because the nation is a political community only in so far as it embodies a common culture and a common social and will' (Smith, 1992, p.62). If both world society and nations legitimate politics in cultural terms, distinguishing between them becomes difficult. Taking a culturally-defined world society to its logical conclusion, we may have to dispense with the concept of nations all together. This inability to come to terms with nations constitutes a significant weakness in Watson's argument. 
Another point to consider is the ES' very restricted notion of culture or civilization. Early ES writings especially are marked by an almost sterile sense of each one of these terms which are used more or less interchangeably. More recent contributions offer more inclusive definitions of both. Duara proposes two different senses: civilization as a universal/universalizing process and as an exclusive/national concept. In the exclusive/national definition, civilization ceases to be a universalizing process and turns into an 'achieved fact' (Duara, 2001, p.123). It is this latter stagnant sense of the term that Watson and the culturalist members of the ES employ in their research.

As a universalizing process, civilization can, at least potentially, extend to 'others'. The very prospect that Turks, identified as the historical 'other' of Europe, may join the EU demonstrates this universalizing potential. One speaker at the European Convention suggested that Europe's boundaries are democracy and human rights, and those prepared to make sacrifices to realize these under a common political framework can join in. There can thus be no 'agreed philosophical or conceptual basis' for rejecting Turkey's or possibly Russia's applications if they are ready to commit to the European project (Bruton, 2002a) in this viewpoint. Another Convention speaker set quite wide boundaries for Europe by declaring that its

borders include Russia and Turkey and the Near East and the northern coast of Africa..... The new Member States will not be a burden but the greatest of challenges, our greatest opportunity. They open to us the possibility of a reassignment of capital and work which will cure us from unemployment and put them on the road for development equal to our own. The new Member States will become the launching pad for the final move which will make Europe a leading power of humanity, as our Continent had been for many thousands of years and as it can so become again (Katiforis, 2002). 
Katiforis' grand vision for Europe is unachievable under Watson's culturally-sterile notion of international society. While purporting to study the role of culture, what Watson ends up doing is to impose culturalism onto international society. This imposing quality is why I employ the term 'culturalist' over 'cultural'. Culturalism, however, does not fare well in our present-day international society which is organized overwhelmingly, if not exclusively, into nation-states. According to Kraus, the chief issue the EU is facing today is its inability to transcend nationalism which resurfaces in a new setting where the discourses and the

institutional workings all imply a more or less continuous reproduction of national structures. In the context of EU politics, this means basically that political interests are legitimized on the grounds of entrenched cultural identities, as long as these identities are those of nation-states (Kraus, 2004, p.51).

Watson's moralistic notion of hegemony is better equipped to deal with the nationstate. The moralistic undercurrent in Watson's writings becomes more pronounced from one of his earliest works, The Nature and Problems of the Third World (1968), to his last, Hegemony and History (2007). The pendulum does not simply describe increasing degrees of supranational authority; it also describes increasing degrees of moral responsibility in international society. In the 'hierarchy of [moral] responsibility', great powers carry the heaviest weight for, above all, maintaining a peaceful international order (Watson, 1982, p.208). This position is far removed from classical realism which divided politics into the two separate realms of utopia and reality, and placed morality to the realm of utopia and power to reality. Power and morality are then treated as 'two different planes which can never meet' (Carr, 2001, p.87). Yet they do meet in the ES for instance in the 'diplomacy of justice', a term Watson (2007, p.85) borrows from a private correspondence with Vincent. This type of 
diplomacy starts from the hegemony point of the pendulum onwards and turns interventions to promote moral values into a routine practice as exemplified in today's highly interventionist post-Westphalian international society (Watson, 2007).

As Clark has already demonstrated, Watson's notion of hegemony bears similarities to Neo-Gramscianism (2011). These two schools are marked off in the broader literature by their emphasis on the ideational or consensual aspects of hegemony rather than on the material only. Cox, the pioneer of Neo-Gramscian theory, describes hegemony as a 'structure of values and understandings about the nature of order that permeates a whole system of states and non-state entities' (Cox \& Sinclair, 1996, p.151) Watson (1992, p.15) describes it as "someone's ability to 'lay down the law' about the operation of the system" yet this is more of a dialogue between those who exercise it and those who are subject to it. Even though they both construe hegemony as an ideational process and point to similar mechanisms as to how it continues, the ES and Neo-Gramscian accounts are not identical. The chief difference between them is the purpose of studying hegemony. While Cox $(1999$, p.12) discusses the 'problem' of hegemony, Watson sees the lack of it as a problem in that a world without hegemony would mean 'permanent and structural insecurity' (1982, p.56). The afterthought to hegemony is the establishment of an emancipatory counter-hegemony in Neo-Gramscian thinking while it is moral responsibility to Watson. In this respect, neither is Neo-Gramscianism immune to the 'Westphalian deferral' (Blaney \& Inayatullah, 2000) in that the international becomes something to be emancipated from as against the possibility contained in Watson's research that it can be morally-loaded.

There is an overlap between the works of Stephen Krasner and Watson as well. Krasner (2001) characterizes the international system as 'organized hypocrisy' where 'norms are 
decoupled from actions' and states violate one another's sovereignty even if they declare their respect for the principle of sovereignty. This occurs because some states are more powerful and there is no central authority to prevent violations of sovereignty. Furthermore, the international system has conflicting norms such as non-intervention and respect for human rights and there is again no authority to adjudicate which norm applies when (Krasner, 2001, p.19). In other words, 'organized hypocrisy' results from the anarchical nature of the system.

Krasner's (2001) analysis is a structural one that more or less suggests 'organized hypocrisy' occurs because it can occur. Watson's is an ideational one based on his concept of 'raison de système' which is 'the belief that it pays to make the system work' (Watson, 1992, p.14, emphasis added). Such hypocrisy occurs because all members of international society share this notion of raison de système, and do not challenge the rules and institutions of international society but violate them in practice. It is why, for instance, what Jackson (1987) calls the 'quasi-states' of post-colonial Africa receive all the ceremonies associated with statehood without meeting most of the material conditions for being a state. The equal status of statehood itself is one of the ways in which we legitimize international society.

In the second section, I will discuss the culturalist and the moralistic approaches within the context of the European Convention by treating each as an ideal-typical supranational system. As Watson (1992) himself notes, the types of systems defined in his pendulum analogy are theoretical abstractions. In practice, the different points in the pendulum blur into another and contain elements of culture, morality as well as material advantage. The most acceptable systems combine all three elements in an 'optimum mix' (Watson, 1992, p.131). The theoretical model is formed through inflated ideal-typical concepts and I compared an ideal- 
typical culturalist EU with an ideal-typical moralistic EU. I concluded that while the culturalist type remained distant to its ideal; the moralistic type did reach it to the extent that possible.

I also studied the views of the ES' Bull and Vincent which I named the 'statist idealtype' in international society. Bull $(1995$, p.309) characterized his research as an 'implicit defense' of the system of states as it is the best possible option to maintain order and justice in international affairs at the same time. I construe Watson's work as an implicit offense against the system of states on the grounds that it fails to consistently deliver the fundamental goals of peace and prosperity. I coined the term 'moralistic' to refer to two things, and I will explicate below why I am choosing the term 'moralistic' over 'moral'. In a primary sense; the moralistic ideal-type assumes that the members of international society will consent to less independence (or more powers to the supranational organs of the EU in this case) to maintain a more peaceful and prosperous order (and not necessarily because their common culture prescribes less independence). In a secondary sense; the moralistic ideal-type requires that this peaceful and prosperous order create rights for the members of world society. Both senses of the term were observed strongly at the European Convention. The third section of the article explains why Neo-Weberian historical sociology is particularly helpful for accounting for deviations in broader international society from this more reachable moralistic ideal-type.

\section{A Watsonian Reading of the European Convention}

The European Convention met between February 2002 - July 2003 for preparing a Draft Treaty Establishing a Constitution for Europe (CT). The purpose was to re-organize the functioning of the Union in the face of its largest round of enlargement at the time. The Convention was attended by representatives from all the member and then candidate states 
and from the Union institutions of Parliament, Commission, Economic and Social Committee, Committee of Regions, Ombudsman and the social partners. The CT created a much more visible Union by making qualified majority voting more or less the norm, and unanimity voting the exception. It introduced a new system of qualified majority voting which replaced unanimity in 20 existing areas of action, and created 20 new areas also to be determined with qualified majority. The two formerly intergovernmental pillars of Common Foreign and Security policy and Justice and Home Affairs were placed under the supranational pillar (European Union, 2015). The strengthening of the powers of the Union was balanced through the strengthening of the role of the member states. The outcome was a "carefully contrived compromise between the positions of the supranational 'federalists' and the 'intergovernmentalists' while at the same time acting as a bridge between the large and the smaller member states" (Evert \& Keohane, 2003, p.19). The 265-page document had to be abandoned after French and Dutch voters rejected it in national referenda in 2005.

I analyzed all the documents submitted to the European Convention to determine if the delegates pointed to a common European culture as a reason for agreeing to more supranational, as opposed to more intergovernmental, rules and institutions in the EU. The pendulum analogy (Watson, 1992) expects this to be the case: a common culture makes it easier to recognize more supranational rules and institutions as legitimate. To verify this proposition, I studied 1300 documents downloaded from the official web site of the European Convention on http://european-convention.europa.eu/bienvenue.asp?lang=EN. The Secretariat assigned different name categories to the materials submitted to the Convention. From among them, 190 'speeches', 158 'documents' and 281 'contributions' in which the various speakers outlined their reasons for or against the introduction of more supranational powers into the EU were particularly useful in my analysis. I then categorized the speakers' 
perspectives for agreeing to more supranational rules and institutions as either cultural or moral. A separate category was created where more supranational rules and institutions were rejected citing state-centric reasons. The purpose of this categorization was to compare the findings against three ideal-typical international societies found in the ES literature: Wight and Watson's culturalist one, Watson's own moralistic one and Bull and Vincent's statist one.

Watson's moralistic ideal-typical international society prevailed in this comparative analysis. Three chief conclusions also emerged. The first is that the idea of a common European culture did figure during the Convention as a normative ideal yet its impact weakened in practice when it came to recognizing new rules and institutions as legitimate. The second is that the primary goals of peace/prosperity along with other moral causes were more favorable reasons for consenting to supranational rules and institutions. The third is that the dominant notion of 'legitimacy' at the Convention was 'legitimacy as equality between the member states of the EU'.

The idea that Europe is or needs to be united through its common culture found strong expression right in the preamble of the CT. After citing the shared 'cultural, religious and humanist inheritance of Europe', it reads that the 'peoples of Europe are determined to transcend their ancient divisions, and united ever more closely, to forge a common destiny' (Draft Constitutional Treaty - Preamble, 2003).

Yet this 'we' failed to provide for the supranationalization of specific policy areas. For instance, the participants at the Convention agreed universally to building a stronger Common Foreign and Security Policy. At the same time, a great majority of them opposed the creation of a European minister of foreign affairs or to some of the other practical arrangements intended to that end. As a French parliamentarian noted, the ideal of European unity 
'disappears when the question of the institutions and powers of the Union is raised: The cleavages here are a measure of the political stakes: considerable' (Badinter, 2002, p.5). The nation-state was what was weakening a European 'we'. Hololei (2003), representing the Estonian government, expressed the nation-state's significance by saying 'What rubbish!' of the Preamble, adding that

the Convention may produce a text that is as beautiful as Shakespeare's in style or contains as much faith as St. Augustine's confessions, it will nevertheless have to be endorsed by the national governments at the intergovernmental conference, thereafter by the national parliaments, and more generally by the people of our countries. Especially please note that the populations of each and every member state will have to be pleased with the outcome, not the mythical "people of Europe". Thus in my opinion it is inevitable that we only maintain our ambitions but a healthy dose of realism as well.

Moral causes, rather than a common culture, legitimized more supranational rules and institutions at the Convention. As Bruton (2002b), representing the Irish parliament, noted; the EU 'came about because some visionary people saw that nationalism, and the idolatry of the nation state, had given us two world wars'. The only option for the future was to carry forward with the process of integration to avoid a return to those days in his view. Europe itself needed to be a space where moral objectives took the center stage. For three speakers from the European Parliament, Europe had to become 'an instrument of solidarity that transcends frontiers and bridges the gaps between different generations and countries, so making the cohesion of society and the eradication of poverty top priorities' (Garrido, Borrell \& Carnero, 2002, p.6).

Watson's (1992) pendulum requires members of international society to choose between order and independence. If there is to be more peace/prosperity, there needs to be less independence. Those at the European Convention have chosen less independence and 
have decided to load this less independent system with specific moral goals. Indeed, Watson (2007, p.85) argued that the members of international society regulate moral issues more forcefully under a 'diplomacy of justice' from the hegemony point of the pendulum onwards. As I argue below, this is how a more and more hegemonic international society facilitates a 'good life' (Jackson, 1990), and this proposition is precisely how Watson avoids the 'Westphalian deferral' (Blaney \& Inayatullah, 2000).

The concept of 'reflexive denationalization' corresponds to this justice-oriented diplomacy whereby 'borders lose their normative dignity, and increasingly universalistic political concepts are developed' (Zürn, 2004, p.266). A similar trend can be observed in the European Community. The Treaty of Rome (1957) focused primarily on economic integration. Subsequent treaties have placed a stronger emphasis on moral principles. During the European Convention, the rights and freedoms of European citizens were treated as an indispensable part of the European order. The Charter of Fundamental Rights, which applies when a Union legislation is being implemented, constituted Part II of the CT for this purpose. The Charter is a pre-existing document that both expands and shifts the bearer of a significant number of rights from EU citizens to non-citizen residents (Guild, 2004). The European Convention thus offered a major example of this type of diplomacy.

Where do these principles of justice come from? The ES theory's answer focused on two sources specified by Bull who also specified two types of international societies on this basis: a pluralist international society whose principles of justice come from positive international law as agreed among states and a solidarist international society whose principles come from natural law. A pluralist international society is founded upon rules of a procedural nature while a solidarist one incorporates moral values as dictated by natural law 
(Bull, 1966). Simply put, a pluralist society is order-oriented while a solidarist society is justiceoriented. The scope and definitions Bull set sparked a prolonged pluralist-solidarist debate in IR theory which has turned particularly divisive at times. Watson has not intervened in this debate as such as his research agenda focuses mainly on structural issues about the exercise of sovereignty. Yet his spectrum of systems does reflect the contours of the pluralist-solidarist debate. As it approaches from independence to empire, the pendulum indicates an increasingly more solidarist international society indeed. However, there is also a stark contrast between Bull and Watson's thinking on this subject. Even though his position increasingly shifted toward solidarism over the years, Bull initially maintained his pluralist stance in unmistakably strong terms. He argued that the solidarist agenda tries to promote Western values based on the wrong presupposition that they are admired all around the world. Moreover, only through the principle of non-intervention in pluralism, he went on to argue, can non-Westerners protect themselves from Western imposition (Bull, 1979). Whereas Watson, with his solidarist instincts, takes the diametrically opposed viewpoint that hegemonic interventionism to promote moral agendas can be acceptable or even desirable. Watson insists that the independence part of the pendulum does not mean more liberty for states or for individuals. Conversely, hegemonic interventionism has done a lot to bring liberty for individuals in many poorly-governed states (Watson, 1997, p. 121).

Even for Watson, however, re-distributive justice presents a particular problem in international society as it can leave some worse-off. He thus maintained that principles of justice in international society are not simply about what is 'right' in a natural law sense but also about what is 'reasonable between states' (Watson, 2007, p.45). I chose the term 'moralistic' over 'moral' precisely to underscore this point that international society exhibits a concern with morality but is not an entirely moral society in a natural law sense. The challenge 
of redistributive issues were mentioned at the European Convention too by, among others, several Dutch speakers who voiced their concern that the Charter of Fundamental rights might 'become substantive EU law which could result in direct claims by citizens against their government' (Vries, Bruijn \& Dijk, 2002, p.68). A compromise was then struck which limited the Charter's applicability to Union legislation (against universal applicability which can override member states' legislation). This compromise ensures that a massive EU does not overwhelm the citizenry and a too empowered citizenry does not overwhelm the member states. This is how a moralistic hegemony proceeds toward creating a 'good life' (Jackson, 1990): through generating rights like those enshrined in the Charter and resolving the contradictions that may arise out of these new rights like the applicability compromise does.

For many at the European Convention, 'equality' was yet another moral principle that had to be indisputable in the new European order. The idea of 'EU legitimacy as equality between the member states' was one of the most salient issues at the Convention. I left second-order senses of the notion of legitimacy such as democracy or transparency aside as my concern was a first-order notion in the sense of the constitutional 'first principles' of international society (Wight, 1977, p.153). 'Equality' was indeed the main first-order sense of legitimacy that emerged from the Convention. Yet how can say a gigantic Germany and a tiny Malta be considered equals? Legitimacy-as-equality is at best an oxymoron but it is the belief that matters. According to the Greek speaker Katiforis (2002), 'there is not the slightest hope of resistance against the giants' in the world without a strong Union. 18 out of 21 membership applicants to the EU were motivated similarly by the 'assumption or belief that the benefit of integration, namely increased national prosperity, is worth the cost in terms of diminished national policymaking autonomy and power' (Mattli, 2000, p.150). 
Earlier I referred to the concept of 'raison de système' which explains the contradictory workings of international society through beliefs rather than through crude structural factors. It also incurs responsibilities on all members to 'ensure that the fabric of the system itself is preserved and its continuity maintained' (Watson, 1982, p.208). In imperial systems especially, an 'element of make-believe' also exists through which the system is legitimized by presenting it as less imperial than it actually is (Watson, 1992, p.130). The CT indeed contains a number of such 'make-believe' elements like disproportionately weighted voting mechanisms amid a much feared prospect of inequality by the smaller members. Still, these elements did not satisfy all. European Parliament member Bonde (2002, p.19) argued that the decision-making mechanisms of the CT meant that the smaller states would soon 'find themselves photocopying the decisions made by the avant-garde countries'. Acknowledging inequality in the EU through a reference to 'avant-garde' countries and insisting on a formal notion of equality is a contradiction which is resolved through beliefs in the EU. If the Europeans can make a very thick supranational system work by laboring to resolve the contradictions it creates, why is it that others in international society do not follow suit? In the third section of the article, I turn to the rationale for resorting to Neo-Weberian research on the state for tackling this question.

\section{Integrating the State into the English School Theory}

One of the advantages of bringing in the ES to the study of supranational systems, and to the study of the EU in particular, is the ability to place these systems under a macro-historical perspective. The EU fits Watson's definition of a dominion where 'an imperial authority to some extent determines the internal government of other communities' but these communities still maintain their separate identities and manage some of their own affairs 
themselves (Watson, 1992, p.15). The nineteenth century Concert of Europe resembled a dominion too. According to Elrod (1976, pp.168-70), the Concert was the first instance of states foregoing interests in order not to be placed outside the moral community of Europe, and convinced states to observe limits for maintaining a peaceful European order. As Shore (2006, p.717) suggests, finding 'complex epithets and neologisms' that describe the EU's alleged uniqueness turned into 'a minor industry' in the academia. A macro-historical approach such as the ES both overcomes this pursuit and enables speculation of the forces that led to a particular dominion back in the nineteenth century or to an EU at present. Only through historical/comparative analyses can we arrive at a systemic theory of supranational systems instead of particular theories of a supranational system called the EU. The valueadded of resorting to the ES approach for considering supranational systems lies here.

Yet states continue to pose a challenge to the argument since some groups of states reach the supranational pendulum points of hegemony/dominion more easily than others, and a common culture alone is not a sufficient explanation. Even the moralistic theory of hegemony that has been vindicated in Europe cannot explain why, for instance, the states of the Middle East rebel against hegemony? (Hinnebusch, 2011). Halliday observes a 'low salience of sovereignty' in the modern Middle East and this sounds quite like Watson as cultural similarities between states should result in this. However, what is happening in the Middle East is not in the positive sense that Watson's narrative sets. Rather, it is a 'function of the disputed character of the political and social regimes within each state and the uses made of this, and the dangers believed to be posed to them, by neighboring states' (Halliday, 2009, pp.16-7). Besides, many of the states in the Middle East are already 'low legitimacy states' due to a combination of historical factors and even the two universalist ideologies of pan-Arabism and pan-Islamism do not provide any momentum for supranational integration under such 
circumstances (Hinnebusch, 2011, p.224). The Middle East thus remains a 'fragmented, economically peripherialized system of weak states' none of which is able to sustain a material or ideological basis for a regional hegemony (Hinnebusch, 2011, p.240). Ayoob (1999, p.249) notes that a regional hegemony can only be instigated by 'pivotal powers' and the acknowledgment of this hierarchical situation as legitimate by the other members of the system. In ES terms, such an acknowledgement refers to a suzerain system whose members are 'in general agreement that there ought to be a suzerain authority' (Watson, 1992, p.15).

Without examining the nature of statehood in different parts of the world, it becomes difficult to explain why a particularly thick suzerain system has developed in Europe and not elsewhere. Two issues need to be raised here. The first is the utility of macro-historical research. If the ES' macro-historical research has advantages, it also has disadvantages in that we cannot utilize it without developing intermediate level concepts to understand contemporary cases (like the contemporary Middle East vs. contemporary Europe). The second and the more profound issue is the status of the state in the argument.

Watson is able to avoid three limiting assumptions in IR theory but not a fourth in that he also operates with a decontextualized/dehistoricized notions of the 'state' as with most other IR approaches. He does emphasize differences between states and also that 'not every part of a complex international system is at the same point along the spectrum at any given time' (Watson, 2007, p.82) but does not elaborate this point. The most fruitful way to account for these regional variations in the pendulum is to study the relevant states. Neo-Weberian approaches are particularly helpful for this purpose.

IR scholars have been searching for a paradigm that does not isolate the domestic and the international for some time now particularly in response to the paucity imposed by 
Neorealism on this point. Many have turned to Neo-Weberian historical sociology and to the works of Michael Mann especially for this purpose (Hobson, 1998a). Neo-Gramscian approaches also answer this paradigm search and their analyses have already entered the study of supranational systems through the Amsterdam School's research on European integration (see Bieler, 2005). Yet the main weakness with the Neo-Gramscian account is that it ends up offering an economistic narrative (as does the Amsterdam School on European integration). As Hobson (1998b, p.357) argues, each one of Neo-Gramscian categories is, in and of itself, defined in class terms. The multi-causal framework of Neo-Weberian historical sociology is a better framework than the economistic Neo-Gramscian one when analyzing structures with many complex variables such as supranational systems of states. A further weakness with Neo-Gramsicanism is that, based on its Marxists heritage, it presupposes emancipatory outcomes through the interplay of contradictory forces in international affairs. The tune of the argument is destroyed if these outcomes never emerge. As already mentioned, emancipatory vs. moralistic approaches distinguish between Neo-Gramscian and ES arguments on hegemony. The moralistic approach is based on the idea that a decent life can be entertained under a hegemonic international society without necessarily leading to emancipatory outcomes. An example I already provided in connection with this point was how the European delegates dealt with the emergence of new issues from the Charter of Fundamental Rights. Neo-Weberianism can accommodate such compromises unlike the Gramscian.

The state itself is construed as an autonomous variable and taken as a 'Janus-faced and adaptive agency within a multi-power and multi-spatial social universe' in the Neo-Weberian view (Hobson, 1998a, p.312). Given that the adaptive capacities of states differ dramatically from one another; what we are forced to do here is to contextualize and historicize processes 
of state formation in different cases, and then utilize the pendulum as a framework of analysis in the developing literature on hierarchy in international society. With his constant emphasis on the subject of dependence/hierarchy, Watson has long been the odd one out in a field preoccupied with anarchy. This preoccupation is increasingly being challenged, and the great historical depth Watson brings into the subject of hierarchy has not gone unnoticed. To name a few, Hobson and Sharman (2005) and Wendt and Friedheim (1995) have already cited Watson in their critiques of the notion of anarchy/independence in IR theory. In Africa, for instance, the particular absence of independence leads to the 'African paradox' in regional community-building efforts as the weak states of the continent are expected to transfer a sovereignty that they lack in the first place to a higher level (Hentz, Söderbaum \& Tavares, 2009, p.214). There is a unique opportunity to cease by placing the works of Michael Mann and Watson in a closer dialogue in understanding such cases as the African paradox. Watson himself points to the overlaps between his work and Mann's by noting that Mann (1986)

arrives at conclusions, coming from another angle, which closely accord with those which I had tentatively reached. For like myself he is clearly interested not only in the generation of power but in how it operated, its radial nature, its limitations and the shifts and compromises which it made, and therefore in the characteristics and functioning of the systems of states, some more imperially organized than others (Watson, 1992, p.10).

Watson is referring specifically to Mann's so-called 'IEMP model' which approaches societies as 'sociospatial networks of power' organized around four sources of social power: ideological, economic, military and political. Each source gives rise to its own institutions which dominate over the others at different periods. Mann presumes a constant interplay among these sources and this is how the historical process continues (1986). As Mann stresses later; not one single political entity has provided for all four sources until the state has emerged in 
history. In Europe, this trend has re-emerged as different entities are again providing for different aspects of life (Mann, 1993, pp.137-9).

If we are to understand why some systems of states are indeed more imperially organized than others (Watson, 1992, p.10), we need to recognize that we cannot study the state and the system of states in isolation from one another. Instead, we need to study the inextricable links between the two and make explicit the ways in which the two spaces constitute one another. One possible route for doing so is to study the correlation between the rise and fall of the social power of the state (Mann, 1986; 1993) and variations in the pendulum observed among groups of states that are under different hierarchical conditions in the international system (Watson, 1992; 1997). Organizing different types of social power is not solely an internal issue as a society has 'never been merely national. It has also been transnational - involving relations that freely cross national boundaries. And it has also been geopolitical - involving the relations between national units' (Mann, 1993, p.118, emphasis in original). If this is so, we must examine thoroughly how transnational/geopolitical and domestic processes affect one another. Most states of the 'African paradox', for example, can be regarded as 'collapsing Hobbesian' states (Mann, 1993, p.136) that occupy the bottom ranks of our contemporary aid/donor hierarchy (Watson, 1997). Given that they surrender most of their economic sovereignty to the donors, how do these Hobbesian states organize their other social powers such as the ideological? Certain states have so firmly monopolized the ideological that what lies beyond-the-state cannot be legitimized in them. A case in point is the development of a Buddhist civilization as a narrative strategy by Sri Lankan intellectuals in their state-building efforts in which they themselves became the leaders of it (Duara, 2001, p.107). How, in comparison, do the various 'semieffective' (Mann, 1993, p.136) states that populate the higher ranks of the same aid/donor hierarchy manage the same processes? In 
some cases, it is this very global hierarchy that creates states and prevents the creation of others. Grovogui (2002) offers a striking example by comparing the cases of Belgium, Switzerland and Congo. The rather unviable states of Belgium and Switzerland owe their development to participating in a particular sovereignty regime in nineteenth century Europe whereas Congo, which could have just as well flourished under a more favorable international environment, was caught up in Europeans' colonial ambitions. Congo eventually became a colony of Belgium and saw its wealth channeled to Europe via Swiss banks (Grovogui, 2002).

As Grovogui (2002) demonstrates forcefully, the international system constrains some like the Congo and enables others like Belgium/Switzerland. Yet Belgium, Switzerland and Congo would all find themselves lumped under the same pendulum metaphor (Watson, 1992). The underlying tension in Watson's research is that there is a disconnect between the more historically-informed parts of his inquiry centered around culture/civilizations and his growing interest in the subject of hegemony/dependency from an international political economy perspective. Buzan has reached a similar diagnosis on Watson (1992) by underlining that he is 'talking mostly about the self-contained sub-global systems of the past rather than about regional sub-systems within a global system' (Buzan, 2004, p.17). It is easier to apply culture-based explanations to the isolated communities of the past than to our contemporary system which is paradoxically both well-connected and deeply divided into nearly 200 nationstates at the same time.

As emphasized earlier, Watson is able to avoid a number of limiting assumptions that prevail in IR theory. Chief among them is the assumption that the international can only be about 'survival' as Wight (1960), among many others, have maintained. Watson has instead maintained that the international too can be 'good'. Another is the assumption that 'territory' 
is the sole source of legitimacy in IR. That there can instead be cultural or moral sources of legitimacy is how Watson escapes this particular limiting assumption. Finally, Watson skillfully demonstrates that much of IR has historically been characterized by hierarchical, rather than anarchical, relations (1992). In this way, Watson avoids the limitations of the anarchy presumption as well. However, he then narrows his own case down by overemphasizing the role of culture in understanding these hierarchical relations. This is how a disconnect opens up in his overall research. Indeed, by focusing solely on culture, we are unable to understand even the European case in contemporary times. I suggested that we need to focus on different processes of state formation to explain why different sub-systems develop in different parts of the world and picked Mann's insights into the state especially for this purpose. There are of course others whose works demonstrate how these processes differ around the world such as Tilly's (1975) research on the European state or Clapham's (1996) on the African.

A dose of his own medicine can also develop Watson's argument further and open up space for new research agendas around the subject of hierarchy in IR. His subsequent research on dependency and how our contemporary international society is organized on the basis of an aid/donor list aligns closely with fresh contributions to this literature (Watson, 1997; 2007). Rezvani (2016), for instance, builds the case that 'partial independence' can be a better option for some territories rather than full independence. This closely accords with some of Watson's ideas. As I examined elsewhere (Ruacan, 2016), Watson (1997) proposed that rather than reify independent statehood, we recognize a category of dependent 'ministates' which have to accept outside involvement in their domestic affairs. With proposals such as this, Watson has constantly challenged dominant theoretical approaches in the field and his challenge remains worthy of further engagement by those who seek to transcend the limitations of conventional orthodoxy in IR theory. There is, moreover, a rightful place for his research to be utilized in 
our efforts to understand the transformation of the EU towards a more morally-loaded entity, and then start theorizing international society as a normative environment as we indeed could have.

*This article benefits from my PhD thesis entitled 'International and World Society: toward an English School Theory of Legitimate Supranational Systems' awarded by the University of Birmingham, UK in December 2014 and partially funded under a Foreign and Commonwealth Office Chevening scholarship. I wish to thank Marco Vieira and Thomas Diez for their thesis supervision, and two anonymous referees of this journal for their comments on an earlier draft of this article. 


\section{REFERENCES}

Agnew, J. (1994). The Territorial Trap: The Geographical Assumptions of International Relations Theory. Review of International Political Economy, 1 (1), 53-80. doi: $10.1080 / 09692299408434268$

Agnew, J. (2005). Sovereignty Regimes: Territoriality and State Authority in Contemporary World Politics. Annals of the Association of American Geographers, 95 (2), 437-461. doi: 10.1111/j.1467-8306.2005.00468.x

Ayoob, M. (1999). From Regional System to Regional Society: Exploring Key Variables in the Construction of Regional Order. Australian Journal of International Affairs, 53 (3), 247-260. doi: $10.1080 / 00049919993845$

Badinter, R. (2002). A European Constitution. European Convention. Retrieved July 2013, from http://european-convention.eu.int/pdf/reg/en/02/cv00/cv00317.en02.pdf

Bieler, A. (2005). Class Struggle over the EU Model of Capitalism: Neo-Gramscian Perspectives and the Analysis of European Integration. Critical Review of International Social and Political Philosophy, 8 (4), 513-526. doi: 10.1080/13698230500205177

Blaney. D., \& Inayatullah, N. (2000). The Westphalian Deferral. International Studies Review, 2 (2), 29-64. doi: 0.1111/1521-9488.00204

Bonde, J.P. (2002). The Convention about the FutureS of Europe. European Convention. Retrieved July 2013, from http://europeanconvention.eu.int/pdf/reg/en/02/cv00/cv00277.en02.pdf

Bruton, J. (2002a). CONV 27/02. European Convention. Retrieved July 2013, from http://european-convention.eu.int/pdf/reg/en/02/cv00/cv00027.en02.pdf 
Bruton, J. (2002b). [Speech]. European Convention. Retrieved July 2013, from http://european-convention.eu.int/docs/speeches/126.pdf

Bull, H. (1966). The Grotian Conception of International Society. In H. Butterfield \& M. Wight (Eds.), Diplomatic Investigations: Essays in the Theory of International Politics (pp. 51-73). London: George Allen \& Unwin.

Bull, H. (1979). The State's Positive Role in World Affairs. Dædalus, 108 (4), 111-123. Retrieved from https://www.jstor.org/

Bull, H. (1995). The Anarchical Society: A Study of Order in World Politics, $2^{\text {nd }}$ edition. New York: Columbia University Press.

Bull, H., \& Watson, A. (Eds.). (1984). The Expansion of International Society. Oxford: Oxford University Press.

Buzan, B. (2001). The English School: an underexploited resource in IR. Review of International Studies, 27 (3), 471-488. doi: 10.1017/S0260210501004715

Buzan, B. (2004). From International to World Society? English School Theory and the Social Structure of Globalization. Cambridge: Cambridge University Press.

Buzan, B., \& Little, R. (2009). Introduction. In A. Watson, The Evolution of International Society: A Comparative Historical Analysis, $2^{\text {nd }}$ edition (pp. x-xxxii). New York: Routledge.

Carr, E.H. (2001). The Twenty Years' Crisis: An Introduction to the Study of International Relations, $2^{\text {nd }}$ edition. New York: Palgrave.

Clark, I. (2011). Hegemony in International Society. Oxford: Oxford University Press. 
Clapham, C. (1996). Africa and the International System: the Politics of State Survival. Cambridge: Cambridge University Press.

Cox, R., \& Sinclair, T. (1996). Approaches to World Order. Cambridge: Cambridge University Press.

Cox, R. (1999). Civil society at the turn of the millennium: prospects for an alternative world order. Review of International Studies, 25 (1), 3-28. Retrieved from https://www.cambridge.org/core/journals/review-of-internationalstudies/issue/62FA19ABCAB8B45AC1DD5447E73DBAFB

Deibert, R. (1997). Exorcismus Theoriae: Pragmatism, Metaphors and the Return of the Medieval in IR Theory. European Journal of International Relations, 3 (2), 167-192. doi: $10.1177 / 1354066197003002002$

Draft Treaty Establishing a Constitution for Europe. (2003). Retrieved July 2013, from http://european-convention.eu.int/DraftTreaty.asp?lang=EN

Duara, P. (2001). The Discourse of Civilization and Pan-Asianism. Journal of World History, 12 (1), 99-130. Retrieved from_https://www.jstor.org/

Dunne, T. (1998). Inventing International Society: A History of the English School. London: Macmillan Press.

Elrod, R.B. (1976). The Concert of Europe: A Fresh Look at an International System. World Politics, 28 (2), 159-174. doi: 10.2307/2009888

European Union. (2015). A Constitution for Europe. Retrieved August 2015, from http://europa.eu/scadplus/constitution/introduction_en.htm 
Evert, S., \& Keohane, D. (2003). The European Convention and EU Foreign Policy: Learning from Failure. Survival, 45 (3), 167-186. doi: 10.1080/00396330312331343537

Garrido, D.L., Borrell, J., \& Carnero, C. (2002). A European Constitution for Peace, Solidarity and Human Rights. European Convention. Retrieved July 2013, from http://europeanconvention.eu.int/pdf/reg/en/02/cv00/cv00329.en02.pdf

Geyl, P. (1948). Toynbee's System of Civilizations. Journal of the History of Ideas, 9 (1), 93-124. doi: $10.2307 / 2707397$

Grovogui, S. (2002). Regimes of Sovereignty: International Morality and the African Condition. European Journal of International Relations, 8 (3), 315-338. doi: doi.org/10.1177/1354066102008003001

Guild, E. (2004). The Variable Subject of the EU Constitution, Civil liberties and Human Rights. European Journal of Migration and Law, 6 (4), 381-394. doi: 10.1163/1571816044088809

Halliday, F. (2009). The Middle East and Conceptions of 'International Society'. In B. Buzan \& A. Gonzalez-Pelaez (Eds.), International Society and the Middle East: English School Theory at the Regional Level (pp.1-23). New York: Palgrave Macmillan.

Hentz, J., Söderbaum, F., \& Tavares, R. (2009). Regional Organizations and African Security: Moving the Debate Forward. African Security, 2 (2-3), 206-217. doi: $10.1080 / 19362200903362109$

Hinnebusch, R. (2011). The Middle East in the world hierarchy: imperialism and resistance. Journal of International Relations and Development, 14 (special issue), 213-246. doi: 10.1057/jird.2010.3 
Hobson, J. (1998a). The 'second wave' of Weberian Historical Sociology - The Historical Sociology of the State and the State of Historical Sociology in International Relations. Review of International Political Economy, 5 (2), 284-320. doi: 10.1080/096922998347570

Hobson, J. (1998b). For a 'second wave' Weberian historical sociology in international relations: a reply to Halperin and Shaw. Review of International Political Economy, 5 (2), 354361. doi: $\underline{10.1080 / 096922998347615}$

Hobson, J., \& Sharman, J. (2005). The Enduring Place of Hierarchy in World Politics: Tracing the Social Logics of Hierarchy and Political Change. European Journal of International Relations, 11 (1), 63-98. doi: 10.1177/1354066105050137

Hololei, H. (2003). Statement on the first part of the draft Constitutional Treaty. European Convention. Retrieved July 2013, from http://europeanconvention.eu.int/docs/speeches/9391.pdf

Jackson, R. (1987). Quasi-states, Dual Regimes, and Neoclassical Theory: International Jurisprudence and the Third World. International Organization, 41 (4), 519-549. doi: $10.1017 / \mathrm{S} 0020818300027594$

Jackson, R. (1990). Martin Wight, International Theory and the Good Life. Millennium: Journal of International Studies, 19 (2), 261-272. doi: 10.1177/03058298900190020901

Katiforis, G. (2002). External Actions of the European Union. European Convention. Retrieved July 2013, from http://european-convention.eu.int/docs/speeches/1447.pdf

Krasner, S. (2001). Rethinking the Sovereign State Model. Review of International Studies, 27 (5), 17-42. doi: 10.1017/S0260210501008014 
Kraus, P. A. (2004). A Union of Peoples? Diversity and the predicaments of a multinational polity. In L. Dobson \& A. Follesdal (Eds.), Political Theory and the European Constitution (pp.4055). London: Routledge.

Lake, D. (2009). Hierarchy in International Relations. Ithaca: Cornell University Press.

Mann, M. (1993). Nation-States in Europe and Other Continents: Diversifying, Developing, Not Dying. Dædalus, 122 (3), 115-140. Retrieved from https://www.jstor.org/

Mann, M. (1986). The Sources of Social Power. Volume I: a history of power from the beginning to A.D. 1760. Cambridge: Cambridge University Press. Retrieved from http://www.sscnet.ucla.edu/soc/faculty/mann/Doc5.pdf

Manners, I., \& Whitman, R. (2016). Another Theory is Possible: Dissident Voices in Theorizing Europe. Journal of Common Market Studies, 54 (1), 3-18. doi: 10.1111/jcms.12332

Manning, C.A.W. (1975). The Nature of International Society. New York: John Wiley and Sons.

Martel, G. (2004). The Origins of World History: Arnold Toynbee before the First World War. Australian Journal of Politics and History, 50 (3), 343-356. doi: 10.1111/j.14678497.2004.00338.x

Mattli, W. (2000). Sovereignty Bargains in Regional Integration. International Studies Review, 2 (2), 149-180. doi: 10.1111/1521-9488.00208

Milner, H. (1991). The Assumption of Anarchy in International Relations Theory: A Critique. Review of International Studies, 17 (1), 67-85. doi: 10.1017/S026021050011232X

Rezvani, D. (2016). Partial Independence Beats Full Independence. Territory, Politics, Governance, 4 (3), 269-296. doi: 10.1080/21622671.2015.1053517 
Ruacan, I. Z. (2016). Post-Conditionality Regimes, EU-Africa Relations and the English School of International Relations. European Review of International Studies, 3 (2), 31-52.

Shore, C. (2006). 'Government Without Statehood'? Anthropological Perspectives on Governance and Sovereignty in the European Union. European Law Journal, 12 (6), 709-724. doi: 10.1111/j.1468-0386.2006.00343.x

Smith, A. (1992). National Identity and the Idea of European Unity. International Affairs, 68 (1), 55-76. Retrieved from https://www.jstor.org/

Tilly, C. (1975). The Formation of Nation States in Europe. Princeton: Princeton University Press.

Vigezzi, B. (2005). The British Committee on the Theory of International Politics (1954-1985): The Rediscovery of History. Milano: Edizioni Unicopli.

Vries, G., Bruijn, T., \& Dijk, J. J. (2002). Suggestion for amendment of Article 5. European $\begin{array}{llll}\text { Convention. } & \text { Retrieved July 2013, from }\end{array}$ http://europeanconvention.eu.int/Docs/Treaty/pdf/5/global5.pdf

Waltz, K. (1979). Theory of International Politics. Reading, MA: Addison-Wesley.

Watson, A. (1968). The Nature and Problems of the Third World. Claremont: The Claremont Colleges.

Watson, A. (1982). Diplomacy: The Dialogue Between States. London: Routledge. 
Watson, A. (1992). The Evolution of International Society: A Comparative Historical Analysis. London: Routledge.

Watson, A. (1997). The Limits of Independence: Relations Between States in the Modern World. London: Routledge.

Watson, A. (2007). Hegemony and History. Routledge, New York.

Wendt, A., \& Friedheim, D. 1995. Hierarchy under Anarchy: Informal Empire and the East German State. International Organization, 49 (4), 689-721. doi: 10.1017/S0020818300028484

Wight, M. (1977). Systems of States, edited by H. Bull. Leicester: Leicester University Press.

Wight, M. (1960). Why is there no International Theory? International Relations, 2 (1), 35-48. doi: $10.1177 / 004711786000200104$

Zürn, M. (2004). Global Governance and Legitimacy Problems. Government and Opposition, 39 (2), 260-287. doi: 10.1111/j.1477-7053.2004.00123.x

\footnotetext{
${ }^{1}$ Blaney and Inayatullah also include parts of a volume co-edited by Bull and Watson (1984) as exemplifying the Westphalian deferral. However, Watson's overall approach sets him apart from both Bull and Wight on this point.
} 